\title{
SOCIAL ENVIRONMENT AND REPRODUCTION
}

\author{
P.H. HEMSWORTH \\ Department of Agriculture, Animal Research Institute; Werribee, Victoria, \\ Australia
}

Social environment is generally considered to consist of visual, tactile, olfactory, auditory and other stimuli which together form the means of communication between individual animals of a species. The role of the social environment on reproduction of domestic animals is a relatively recent topic for research but with recent developments in animal production it is assuming greater importance. Intensification of animal production has and will continue to produce marked changes in the social environment of the animal and thus it is essential that scientists, advisers and producers are aware of its role in reproduction. In a review of reproductive disorders of pigs, Wrathall (1975) suggested that many of the disorders encountered in intensive pig production originate from neglect or ignorance of the importance of social factors. Thus, failure to provide an environment in which reproduction can proceed naturally and efficiently will result in reproductive failure. It is the object of this chapter to review the current state of knowledge of the role of the social environment on reproduction of the boar, gilt and sow.

\section{Sexual stimuli and immediate sexual behaviour}

Courtship and copulation consist of a sequence of specific responses to specific stimuli from the partners which lead to the successful insemination of the female. The stimuli involved in sexual behaviour have been classified by Schein and Hale (1965) into three functional types i.e. broadcast, identification and synchronizing stimuli. It is useful to consider briefly the sexual stimuli of the pig in these three classes.

\section{BROADCAST STIMULI}

According to Schein and Hale (1965), these serve to advertize the availability of an individual and thereby, elicit approach responses on the part of potential partners to bring them into spatial proximity. During oestrus the exploratory activity of the sow greatly increases (Signoret, $1970 \mathrm{a}, \mathrm{b})$ and sensory signals from the boar provide strong attraction for the sow (Signoret, 1972). However, in T-maze experiments boars were 
observed to show similar attraction to oestrous and dioestrous sows (Signoret, 1970b, 1971). Therefore, since the sow's exploratory activity appears to be largely oriented by stimuli from the boar and the boar is less sensitive to broadcast-type stimuli from the oestrous sow, the oestrous sow plays the active role in bringing the two sexual partners together.

\section{IDENTIFICATION STIMULI}

These are stimuli that signal the sexual receptivity of the individual and are released in response to cues from the potential partner (Schein and Hale, 1965). The initial courtship display of the boar is an identification stimulus and the 'standing response' or immobility response (Signoret, 1970a) by the sow reveals her receptivity. Pressure on the back, odour of the boar and frequency and rhythm of the courting grunts of the boar have been identified as the main stimuli eliciting the standing response in the sow (Signoret, 1970a,b). The important role of olfactory and auditory stimuli explains the significance of the high level of naso-nasal contact between the boar and sow during courtship (Signoret, 1970a,b).

Since the boar is attracted to and courts an oestrous or dioestrous sow in a similar manner (Signoret, 1970b), it appears that the boar detects that the sow is in oestrus by her behavioural response to his stimulation.

\section{SYNCHRONIZING STIMULI}

These govern the coordination of the motor patterns leading to the successful insemination of the female (Schein and Hale, 1965). The signals are emitted once the partner shows receptivity via the identification stimuli. The main stimulus which releases mounting behaviour in the boar appears to be the visual cue(s) from the shape and immobility of the sow diplaying the standing response (Fraser, 1968a; Signoret, 1970b). The pressure of the cervix on the glans penis is the essential stimulus for ejaculation (Walton, 1960).

In addition to the role of sexual stimuli on the achievement of insemination, these stimuli may also have an immediate influence on the partner's physiological mechanisms and influence the chances of fertilization. Fraser (1968b) has suggested that genital stimulation by the male will accelerate uterine motility and thus sperm transport in the female. Similarly, Signoret (1972) proposed that sexual stimuli from the boar during mating may influence reproductive efficiency of the sow. He has suggested that the presence of the courting boar may explain the difference in farrowing rates to natural and artificial insemination. This proposal is supported by recent observations at Werribee on the sexual behaviour of 24 commercial boars. Those which displayed a high frequency of nosing the flanks of the sow during courtship had a higher farrowing rate (percentage of mated sows that farrowed) than those of lower 'nosing activity' (Hemsworth, Beilharz and Brown, 1978). Döcke and Worch (1963) reported that the presence and behaviour of the boar during courting led to an increase in uterine contractions in the sow, and Pitkjanen (1964) has shown that the physical 
presence of the boar increases the transit of spermatozoa along the uterine horns. Thus increased nosing activity by the boar may stimulate uterine contractions in the sow and thereby increase sperm transport, the number of spermatozoa in the oviduct and consequently the chances of fertilization. An alternative explanation arises from the work of Signoret, du Mesnil du Buisson and Mauleon (1972) who reported that a stimulus or stimuli associated with mating advanced the timing of ovulation and possibly improved the timing of fertilization.

Sexual stimuli may also influence physiological mechanisms involved in reproduction of the boar. As with bulls, sexual stimulation before semen collection, achieved by brief restraint after mounting or observation of a mating, will increase the number of spermatozoa in the ejaculate of the boar (Hemsworth and Galloway, 1979).

Thus, sexual stimuli from the partners have an important role in the achievement of insemination of the sow and, perhaps, the success of the insemination.

\section{Prepubertal social environment of the boar}

Until recently, little was known of the influence of the social environment during rearing on reproduction of the pig. This is surprising since there is considerable variation in the amount and type of social contact that the young breeding pig may receive in modern pig production. Studies with a number of laboratory species including the guinea pig, rat and rhesus monkey, have demonstrated the importance of social contact during rearing on sexual behaviour (Young, 1957; Young, Goy and Phoenix, 1968). Males that had been socially deprived from an early age showed a serious inability to properly orient towards, mount and clasp the receptive female. Similarly, females reared with limited social contact displayed poor oestrous behaviour, as indicated by a reduction in the duration of the standing response.

In view of these reports a series of studies was conducted to investigate the influence of the prepubertal social environment on the development of the sexual behaviour of the boar (Hemsworth, Beilharz and Galloway, 1977; Hemsworth, Findlay and Beilharz, 1978; Hemsworth and Beilharz, 1979). Boars reared from 3-30 weeks of age without visual or physical contact with pigs ('social restriction') achieved fewer copulations and displayed less courting behaviour in a series of mating tests than boars reared in either an all-male or mixed sex group (Table 28.1). Since the mating dexterity of the socially-restricted boars appeared satisfactory, it was likely that they were of low sexual motivation. The rearing treatments had no effect on size of the testicles or semen quality.

A subsequent study indicated that lack of physical contact with pigs per $s e$ was predominantly responsible for the depression in the level of sexual behaviour caused by lack of both physical and visual contact with pigs during rearing (Table 28.2). Comparison of the sexual behaviour of boars reared in social restriction from either 3 or 12 weeks of age shows that the age of the boar when first deprived of social contact influences the extent to which the level of sexual behaviour is depressed (Table 28.2). 
Table 28.1 THE SEXUAL BEHAVIOUR OVER 12 MATING TESTS OF BOARS REARED IN SOCIAL RESTRICTION (VISUAL AND PHYSICAL ISOLATION FROM PIGS, GROUP A). AN ALL-MALE GROUP (B) AND A MIXED SEX GROUP (C)

\begin{tabular}{lrrr}
\hline & \multicolumn{3}{c}{ Rearing treatment } \\
\cline { 2 - 4 } & $A$ & \multicolumn{1}{c}{$B$} & \multicolumn{1}{c}{$C$} \\
\hline $\begin{array}{l}\text { Number of copulations/boar (mean) } \\
\text { Sum of all courting behaviour } \\
\text { activities/boar (mean) }\end{array}$ & $2.1^{y}$ & $10.6^{x}$ & $8.5^{x}$ \\
\hline
\end{tabular}

$x_{1}$, means in the same row with a different superscript differ significantly $(P<0.01)$

From Hemsworth, Beilharz and Galloway (1977)

Table 28.2 SEXUAL BEHAVIOUR OVER 20 MATING TESTS OF BOARS REARED TO 32 WEEKS OF AGE IN SOCIAL RESTRICTION (VISUAL AND PHYSICAL ISOLATION FROM PIGS) FROM 3 WEEKS (A) AND FROM 12 WEEKS (B), PHYSICAL ISOLATION FROM PIGS FROM 3 WEEKS (C) AND IN AN ALL-MALE GROUP (D)

\begin{tabular}{lrrrr}
\hline & \multicolumn{4}{c}{ Rearing trearment } \\
\cline { 2 - 5 } & \multicolumn{1}{c}{$A$} & \multicolumn{1}{c}{$B$} & \multicolumn{1}{c}{$C$} & \multicolumn{1}{c}{$D$} \\
\hline $\begin{array}{l}\text { Number of copulations/boar (mean) } \\
\begin{array}{l}\text { Sum of all courting behaviour } \\
\text { activities/boar (mean) }\end{array}\end{array}$ & $8.8^{b}$ & $13.8^{a b}$ & $13.3^{a b}$ & $24.0^{a}$ \\
\hline
\end{tabular}

${ }^{a . b}$ : means in the same row with a different superscript differ significantly $(P<0.05)$

From Hemsworth. Findlay and Beilharz (1978)

A final study examined the effects on sexual behaviour of rearing boars in individual wiremesh pens which allowed restricted physical contact with neighbouring boars. Rearing from either 3 or 12 weeks of age in these individual pens did not adversely affect the copulatory performance of the boars (Hemsworth and Beilharz, 1979). However, boars reared in these pens from three weeks of age displayed low levels of nosing activity which is apparently an important component of courtship. As previously discussed, the level of nosing activity by the boar during courting may affect the proportion of mated females that farrow.

These studies did not investigate the influence of olfactory contact with females. According to Booth and Baldwin (1980), the removal of the olfactory lobes at $10-12$ weeks of age does not significantly affect the sexual behaviour of the boar. This suggests that olfactory communication with female pigs from this early age is not critical in the development of the sexual behaviour of the boar. However, the test used to assess sexual behaviour was qualitative and hence it is unlikely that it could discriminate between boars of varying levels of sexual behaviour. The test would assess mating competency and it appears that olfactory bulbectomy does not adversely affect the ability and capacity of the boar to display the motor patterns leading to copulation.

Prepubertal social environment also appears to influence the age when the boar first displays a fully coordinated mating response to an oestrous female. Boars reared in groups displayed the mating response at an earlier age then those reared in individual pens (Thomas et al., 1979). The age of attainment of the mating response was not significantly different for boars housed in groups with or without contemporary gilts. However, all boars 
were exposed weekly to an oestrous female, presumably from an early age, to observe the attainment of the mating response. Further, whether the boars had olfactory contact with females outside the rearing pens was not reported. Thus, contact with female pigs during rearing may have been effectively similar between the two rearing treatments.

Thus, social environment during rearing will exert a major influence on the level of sexual behaviour of the boar. Physical contact with pigs appears to be a critical aspect of the social environment in this regard. Failure to provide the young boar with physical contact with pigs will severely impair his subsequent level of sexual behaviour.

\section{Postpubertal social environment of the boar}

There is little information in the literature on the influence of the presence of the female on reproduction of the male. Observations on adult male rhesus monkeys during the non-breeding season showed that the normally sexually quiescent males can be returned to a sexually active state by exposure to oestrogen-treated females (Vandenbergh, 1969). The female rhesus monkey appears to signal her receptivity to the male by way of behavioural displays and pheromones (Michael and Zumpe, 1970; Michael et al., 1972). During the breeding season rams continually exposed to sexually receptive ewes achieved a greater number of copulations in a single mating test than rams isolated from ewes (Illius, Haynes and Lamming, 1976). Recent studies at our laboratory also suggest that the presence of the female pig will influence the level of sexual behaviour of the mature boar.

Isolation of mature boars from female pigs severely reduces their level of sexual behaviour (Hemsworth et al., 1977). However, housing them near to sexually receptive females successfully restores their level of sexual behaviour. A recent study revealed that the presence of sexually receptive or sexually non-receptive females was equally effective in stimulating the sexual behaviour of the mature boar (Table 28.3). Thus, the mature boar requires the stimulation from the presence of female pigs, regardless of their oestrous status, to maintain his potential level of sexual behaviour.

The type of stimulus (or stimuli) responsible for this effect has not been identified. However, olfactory and, to a lesser extent, auditory stimuli appear to be the most likely, since postpubertal boars housed 8 or $15 \mathrm{~m}$

Table 28.3 SEXUAL BEHAVIOUR OVER 9 MATING TESTS OF MATURE BOARS HOUSED IN ISOLATION FROM FEMALES (A), NEAR SEXUALLY NON-RECEPTIVE FEMALES (B) AND NEAR SEXUALLY RECEPTIVE FEMALES (C)

\begin{tabular}{lrrr}
\hline & \multicolumn{3}{c}{ Treatment } \\
\cline { 2 - 4 } & \multicolumn{1}{c}{$A$} & \multicolumn{1}{c}{$B$} & \multicolumn{1}{c}{$C$} \\
\hline $\begin{array}{l}\text { Number of copulations/boar (mean) } \\
\text { Sum of individual courting behaviour } \\
\text { activities/boar (mean) }\end{array}$ & $4.4^{a}$ & $6.1^{b}$ & $6.3^{b}$ \\
\hline
\end{tabular}

\footnotetext{
${ }_{a, b}$ : Means in same row with a different superscript differ significantly $(P<0.05)$

$x . y$ : Means in same row with a different superscript differ significantly $(P<0.01)$

From Hemsworth, Winfield and Chamley (1981)
} 
from female pigs have little visual or gustatory contact with females but display similar levels of sexual behaviour to those housed $3 \mathrm{~m}$ from females (Table 28.4).

Table 28.4 THE SEXUAL BEHAVIOUR OVER 6 MATING TESTS OF 15 MATURE BOARS HOUSED 3, 8 AND $15 \mathrm{~m}$ FROM FEMALE PIGS

\begin{tabular}{lccc}
\hline & \multicolumn{3}{c}{ Distance of boar from female pigs } \\
\cline { 2 - 4 } & $3 \mathrm{~m}$ & $8 \mathrm{~m}$ & $15 \mathrm{~m}$ \\
\hline $\begin{array}{l}\text { Number of copulations/boar (mean) } \\
\begin{array}{l}\text { Sum of individual courting behaviour } \\
\text { activities/boar (mean) }\end{array}\end{array}$ & 5.0 & 5.4 & 5.2 \\
\hline
\end{tabular}

The results of a study by Booth and Baldwin (1980) may be useful in this discussion. If an olfactory stimulus or stimuli from the female is important in maintaining the level of sexual behaviour of the mature boar, then olfactory bulbectomy, irrespective of when it occurred, would be expected to reduce the level of sexual behaviour of the mature boar. However in this study sexual behaviour was not affected. As discussed earlier, it is possible that the behavioural test used may not have been able to clearly discriminate between boars of varying levels of sexual behaviour.

Thus, as with the social environment during rearing, the social environment after puberty has a marked influence on the level of sexual behaviour of the boar. A stimulus or stimuli from the female pig appears to be necessary to maintain the potential level of sexual behaviour of the mature boar.

\section{Prepubertal social environment of the gilt}

In contrast to the boar, considerably more research has been conducted on the effect of the prepubertal social environment on reproduction of the gilt, possibly because the practical implications are more apparent. It is now well established that the introduction of a mature boar to immature gilts induces the precocious attainment of puberty (Brooks and Cole, 1970; Hughes and Cole, 1976, 1978). This male effect on puberty in the gilt is discussed in detail in Chapters 6 and 7.

Initial studies on male effect were predominantly concerned with attainment of puberty and little attention was paid to reproductive efficiency of the gilt. However, Hughes and Cole (1978) noted that gilts not previously exposed to boars exhibited agitation, an inadequate standing response and a marked reduction in mating rate (defined as the percentage of gilts exhibiting a standing heat that were successfully mated) when first introduced to a boar at their second oestrus (Table 28.5). Kirkwood and Hughes (1980a) also reported that gilts having had no boar contact before second oestrus and having changed pens daily from 165 days of age, showed an increased tendency not to stand for the boar, with a result that mating rate was reduced. However, the control gilts (those that did not receive boar stimulation or change pens) had a similar mating rate to those exposed to boars from 165 days of age. 
Table 28.5 AGE AT PUBERTY AND MATING RATE AT SECOND OESTRUS OF CONTROL (C) GILTS, AND GILTS GIVEN OESTRADIOL BENZOATE (E) AND BOAR CONTACT (B)

\begin{tabular}{lllll}
\hline & \multicolumn{4}{c}{ Treatment groups } \\
\cline { 2 - 5 } & $E+B$ & $E$ & $C+B$ & $C$ \\
\hline Mean age at puberty (days) & $153.2^{x}$ & $160.1^{y}$ & $159.5^{z}$ & $176.0^{x y z}$ \\
Mating rate (\%) & 100 & 50 & 80 & 77.8 \\
Pregnancy rate at 20 days (\%) & 100 & 100 & 100 & 85.7 \\
\hline
\end{tabular}

$x, y, z$ : means in same row with a different superscript differ significantly $(P<0.01)$

From Hughes and Colé (1978)

Observations from a recent study at our laboratory also indicated a marked reduction in mating rate (defined as the percentage of oestruses in which a successful copulation occurred) at the pubertal and subsequent hormone-induced oestruses of gilts reared in isolation from boars (treatment groups A and B in Table 28.6). The main reasons for reduced mating rate were failure to stand for the boar and failure of duration of ejaculation to exceed the 1.5 minutes that has been defined as necessary for a successful copulation. At the pubertal oestrus, ovulation without overt oestrus also contributed to mating failure. In addition, gilts isolated from boars during rearing took longer to display the standing response after the boar had mounted and the gilts terminated a higher proportion of copulations in a series of mating tests. Thus, both oestrus expression and sexual receptivity of the gilt appear to be adversely affected by rearing in isolation from boars.

When gilts were reared near mature boars, those that received regular boar introduction during rearing had a higher mating rate (Table 28.6).

Table 28.6 OESTROUS BEHAVIOUR AT THE PUBERTAL AND THREE SUBSEQUENT INDUCED OESTRUSES OF 40 GILTS REARED FROM FOUR WEEKS OF AGE IN SOCIAL RESTRICTION (NO VISUAL OR PHYSICAL CONTACT WITH PIGS) AND ISOLATED FROM BOARS (A), A GROUP ISOLATED FROM BOARS (B), A GROUP WITHIN 3 m OF MATURE BOARS (C) AND A GROUP NEAR MATURE BOARS AND INTRODUCED TO A MATURE BOAR THREE TIMES PER WEEK (D)

\begin{tabular}{|c|c|c|c|c|}
\hline & \multicolumn{4}{|c|}{ Rearing treatment groups } \\
\hline & $A$ & $B$ & $C$ & $D$ \\
\hline $\begin{array}{l}\text { Pubertal oestrus } \\
\text { Mating rate }(\%) \\
\text { Matings in which the gilt terminated the } \\
\text { copulation }(\%)\end{array}$ & $\begin{array}{l}30.0^{x} \\
70.0^{z}\end{array}$ & $\begin{array}{l}50.0^{y} \\
30.0^{y}\end{array}$ & $\begin{array}{l}87.5^{z} \\
10.0^{x}\end{array}$ & $\begin{array}{r}90.0^{x} \\
0.0^{x}\end{array}$ \\
\hline $\begin{array}{l}\text { Pubertal and induced oestruses } \\
\text { Mating rate (\%) } \\
\text { Average time from when the boar } \\
\text { mounted until the gilt displayed the } \\
\text { standing response (s) } \\
\text { Matings in which the gilt terminated the }\end{array}$ & $\begin{array}{l}72.5^{x} \\
24.1^{b}\end{array}$ & $\begin{array}{l}73.7^{x} \\
32.7^{b}\end{array}$ & $\begin{array}{l}78.9^{y} \\
16.0^{a}\end{array}$ & $\begin{array}{r}92.5^{2} \\
5.0^{\circ}\end{array}$ \\
\hline copulation (\%) & & & & \\
\hline
\end{tabular}

$\overrightarrow{a, b}:$ Means in same row with different superscript differ significantly $(P<0.05)$

${ }_{1}, y$ : Means in same row with different superscript differ significantly $(P<0.01)$

From Hemsworth. Cronin and Hansen (1982) 
Increased boar contact of this group D compared with gilts housed $3 \mathrm{~m}$ from boars (group C) may have been responsible for this difference in mating rate and it appears that a progressive increase in mating rate was associated with the increased boar contact during rearing.

On the basis of observations on the attraction by a male and the standing response to a back pressure test of gilts reared either in the absence or presence of boars, Signoret (1970c) concluded that the sexual behaviour of the gilt was not influenced by prepubertal social environment. However, Signoret did not observe the level of the sexual response of the gilts when introduced to a boar.

Further research is needed to identify the nature of the stimulus from the mature boar which is responsible for the effect on oestrous behaviour of the gilt. The timing and duration of mature boar contact also requires investigation. It is interesting that Hughes and Kirkwood (1980) reported that the stimulus from the mature boar responsible for early attainment of puberty in the gilt is olfactory in nature and that the production of this pheromone is age dependent. Mature boar contact during rearing does not appear to significantly influence conception rate, ovulation rate and litter size of the gilt (Hughes and Cole, 1976, 1978; Hughes and Kirkwood, 1980; Kirkwood and Hughes, 1979, 1980a,b).

In comparison with group housing during rearing, the housing of gilts either in tethers or in individual pens appears to delay the onset of puberty (Jensen et al., 1970; Robison, 1974; Mavrogenis and Robison, 1976). In addition, type of housing may also affect the mating rate of gilts. Gilts reared in social restriction and isolated from boars (group A) had a lower mating rate at the pubertal oestrus than gilts reared in groups but isolated from boars (group B) (Table 28.6). Difficulties with oestrus expression, such as a reduction in the duration of overt oestrus and even a failure to display overt oestrus, were the main reasons for the reduced mating rate in the group A gilts. Jensen et al. (1970) also reported that gilts reared in tethers and in groups in pens had a $68 \%$ and $92 \%$ mating rate, respectively. Further, England and Spurr (1969) reported $83 \%$ and $94 \%$ mating rates-in gilts housed in individual and group pens respectively, from approximately 7.5 months of age. In both studies a higher frequency of ovulation without overt oestrus was observed in the individually-housed gilts. However, in these two studies the gilts remained on their rearing treatments during oestrus and this, rather than the rearing treatment itself, may have been responsible for the reduction in oestrus expression.

Thus, in addition to the adverse influence on the attainment of puberty, the absence of mature boar contact during rearing appears to adversely affect the reproductive efficiency of the gilt by influencing oestrus expression and sexual receptivity. There is some evidence to suggest that individual housing, either in tethers or in individual pens during rearing, will also reduce the expression of oestrus in the gilt.

\section{Postpubertal social environment of the sow}

There is considerable evidence in the literature that the presence of the male can modify or regulate the sexual activity of the female. Synchronization and induction of oestrus occurs with the introduction of a mature male 
mouse into a colony of female mice (Whitten, 1956; 1959). A similar phenomenon occurs in the ewe. Introduction of a ram to a group of ewes prior to the commencement of the breeding season synchronizes and induces oestrus much earlier than otherwise would occur (Schinckel, 1954; Watson and Radford, 1960). Post-weaning anoestrus is one of the commonest reproductive disorders in sows, particularly first-litter sows, (Wrathall, 1975; Meredith, 1979) and yet, surprisingly, the influence of the social environment on the induction of oestrus following parturition or weaning has received little attention from research workers.

Although the period of lactation in the sow is characterized by a suppression of oestrus, probably due to the inhibiting influence of the suckling stimulus (Peters, First and Casida, 1969), a number of studies have demonstrated that the combination of several factors, including social factors, will induce a fertile oestrus during lactation (Rowlinson, Boughton and Bryant, 1975; Rowlinson and Bryant, 1976). Attempts to repeat these studies have produced equivocal results, for which variation in the quality and quantity of these factors may have been responsible.

Ad libitum feeding, grouping and the continuous presence of a boar within the group after day 20 or 21 of lactation were associated with the successful induction of oestrus in lactating sows (Rowlinson, Boughton and Bryant, 1975; Rowlinson and Bryant, 1976). An acceptable conception rate was achieved with mating at this oestrus in the first study. According to Brooks (1974), Rowlinson found that the occurrence of lactational oestrus was reduced from $80 \%$ to $40 \%$ when a boar was housed in an adjacent pen rather than with the sows.

In contrast, several studies have reported a low incidence of lactational oestrus. Lactating sows fed ad libitum, individually housed and introduced daily to a boar for 10-15 minutes from day 10 of lactation failed to show oestrus during lactation (Cole, Brooks and Kay, 1972). A small percentage of lactating sows separated from boars exhibited oestrus following restricted feeding and housing in either individual pens $(1.3 \%)$ or group pens $(2.6 \%)$ from day 10 of lactation (Petchey, Dodsworth and English, 1978). Housing sows in groups with the majority adjacent to, rather than with a boar, from day 14 of lactation and feeding the sows $6.4 \mathrm{~kg}$ of feed/day during lactation resulted in $48 \%$ of the lactating sows exhibiting oestrus (Petchey and Jolly, 1979). It is of interest that in this study sows mated during lactation had a higher liveweight at weaning than those mated after weaning.

Therefore, in combination with ad libitum feeding, there is evidence to suggest that lactational oestrus can be successfully induced by housing sows in groups and housing a boar within the group. However, it is obvious that further research is required in which the quality and quantity of these factors is adequately controlled and described. For example, in all the above-mentioned studies the age of the boar was not reported and yet this may be an important factor particularly in the light of the study by Hughes and Kirkwood (1980) on the importance of the age of the boar on puberty induction in the gilt.

Even less research has been conducted on the influence of the social environment on the onset of oestrus in the weaned sow. Hillyer (1976) reported that the weaning to conception interval was reduced from 27 to 9 
days by spraying sows shortly after weaning with a synthetic boar odour containing the steroid $5 \alpha$-androst-16-en-3-one. It appears that an aerosol spray containing this steroid will induce the standing response in the oestrous female (Melrose, Reed and Patterson, 1971) and thus, it is not clear whether the synthetic boar odour used by Hillyer stimulated the onset of oestrus or aided oestrous detection.

A survey of 75 Norwegian piggeries found that weaning to mating interval was not significantly affected by housing weaned sows in either the presence or absence of boars (Karlberg, 1980). However, little information on the social environment, apart from the presence or absence of a boar, was provided by the author. In contrast; a recent study conducted on 1100 sows in the Netherlands indicated that the factors of intense boar stimulation, achieved by daily introduction to a mature boar, and group housing were significantly associated $(P<0.005$ and $P<0.05$, respectively) with an earlier oestrus after weaning in the sow (Table 28.7). Examination of the

Table 28.7 THE INFLUENCE OF POST-WEANING SOCIAL TREATMENTS OF INDIVIDUAL (I) OR GROUP (G) HOUSING AND PRESENCE $\left(+\sigma^{\circ}\right)$ OR ABSENCE $\left(-\sigma^{\prime}\right)$ OF DAILY BOAR INTRODUCTION ON THE WEANING TO MATING INTERVAL

\begin{tabular}{lcccc}
\hline & \multicolumn{4}{c}{ Treasment groups } \\
\cline { 2 - 5 } & $I-\sigma$ & $I+\sigma^{\prime}$ & $G-\sigma^{\prime}$ & $G+\sigma^{\prime}$ \\
\hline Average weaning to mating interval & 16.5 & 14.4 & 15.7 & 11.7 \\
(days) & $(23.9)^{(\mathbf{a})}$ & $(20.8)$ & $(22.0)$ & $(16.4)$ \\
Sows mated by day 10 after weaning & 46.8 & 54.3 & 49.1 & 64.3 \\
$(\%)$ & $(9.7)$ & $(24.1)$ & $(13.3)$ & $(48.1)$ \\
\hline (a) & & & &
\end{tabular}

(a)Figures in parentheses are data for first-litter sows.

From Hemsworth, Salden and Hoogerbrugge (1982)

ovaries of unmated sows and observations on the response of unmated sows to pregnant mare's serum gonadotrophin/human chorionic gonadotrophin (PMSG/HCG) injection suggested that these social treatments were stimulating the onset of oestrus rather than affecting the efficiency of oestrus detection. Surprisingly, daily introduction of a mature boar for 10 minutes into an area adjacent to weaned sows failed to significantly affect the onset of oestrus. Therefore, an element(s) involved with daily movement and introduction to a mature boar appears to stimulate the onset of oestrus in the weaned sow. Research presently being conducted in the Netherlands supports this finding. The proximity of mature boars was not significantly associated with the weaning to mating interval, while daily introduction to a mature boar for the first seven days after weaning significantly $(P<0.05)$ advanced the onset of oestrus (Table 28.8). Further research is required to identify the element(s) involved in movement and introduction to a mature boar that is influencing the onset of oestrus. Olfactory bulbectomy disrupted ovarian activity in postpubertal gilts (Signoret and Mauleon, 1962) and thus, an olfactory stimulus, or stimuli, from the courting boar is likely to be involved in the stimulatory effect on oestrus. The study by Hughes and Kirkwood (1980) on the importance of the olfactory stimulus from boars on puberty induction of the gilt, tends to support this view.

The results of studies on the influence of the penning system on 
Table 28.8 THE INFLUENCE OF THE POST-WEANING SOCIAL TREATMENTS OF HOUSING WITHIN $3 \mathrm{~m}$ OR GREATER THAN $9 \mathrm{~m}$ OF MATURE BOARS AND THE PRESENCE $\left(+\sigma^{\prime}\right)$ OR ABSENCE $\left(-\sigma^{\prime}\right)$ OF DAILY BOAR INTRODUCTION ON THE WEANING TO MATING INTERVAL

\begin{tabular}{lcccc}
\hline & \multicolumn{4}{c}{ Treatment groups } \\
\cline { 2 - 5 } & $9 m-\sigma^{7}$ & $9 m+\sigma^{2}$ & $3 m-\sigma^{7}$ & $3 m+\sigma^{\prime}$ \\
\hline Weaning to mating interval & 12.9 & 11.2 & 11.9 & 10.0 \\
(days) & $(18.7)^{(\mathrm{a})}$ & $(17.0)$ & $(17.6)$ & $(11.9)$ \\
Sows mated by day 10 post-weaning & 54.0 & 61.7 & 61.0 & 69.7 \\
$(\%)$ & $(20.0)$ & $(21.4)$ & $(16.7)$ & $(53.3)$ \\
\hline
\end{tabular}

(a) Figures in parentheses are data for first-litter sows.

From Salden and Hoogerbrugge (unpublished data)

reproduction of the sow are contradictory. Variation in such factors as group size, space allowance, tethering or loose housing, pen design, contact with pigs and feeding system may be predominantly responsible for this conflict. Sommer (1980) reported a shorter weaning to mating interval for sows housed in groups rather than in individual pens (7.9 and 23.0 days, respectively) and Hemsworth, Salden and Hoogerbrugge (1982) found that group housing from weaning to mating was associated with a significantly earlier oestrus (Table 28.7). No significant difference in this interval was reported in sows housed either in groups or individual pens (England and Spurr, 1969; Fahmy and Dufour, 1976; Karlberg, 1980). However, Maclean (1969) reported a shorter interval for sows housed individually rather than in groups ( 9.0 and 11.5 days, respectively).

While the above studies on the weaning to mating interval provide inconsistent results, studies on the influence of the post-weaning penning system suggest that individual housing may be associated with a reduction in fertility. A higher conception rate was reported for sows housed in groups of 5-6 after weaning than for sows individually housed $(87.2 \%$ and $82.4 \%$, respectively) (Knap, 1969). Fahmy and Dufour (1976), in an attempt to demonstrate the adverse effects of stress caused by grouping, found that sows housed after weaning in groups of 8-10 animals had a higher pregnancy rate at $\mathbf{4 2}$ days than sows individually housed $(81.1 \%$ and $66.5 \%$, respectively). Similarly, Hemsworth, Beilharz and Brown (1978) observed that sows housed in pairs after weaning had a higher farrowing rate and litter size (born alive) than those housed in individual pens (farrowing rates were $86.7 \%$ and $50.0 \%$, respectively; litter sizes were 10.31 and 6.67 , respectively). All sows were briefly courted by a boar prior to artificial insemination. A higher litter size (total piglets born) was also found for sows housed in groups of four from weaning to mating than for those individually housed during this period (10.91 and 10.69, respectively) (Hemsworth, Salden and Hoogerbrugge, 1982).

The problems associated with research on the influence of the penning system on reproduction of the sow are further highlighted in an examination of the literature on the role of the penning system during gestation. The results of a number of studies on this subject are given in Table 28.9. Clearly the results of studies with the gilt are inconclusive; however, those with the sow indicate a tendency for a reduction in conception rate or 
Table 28.9 THE INFLUENCE OF THE PENNING SYSTEM AT MATING AND DURING GESTATION ON THE FERTILITY OF THE GILT AND SOW

\begin{tabular}{|c|c|c|}
\hline \multirow[t]{2}{*}{ Study } & \multicolumn{2}{|c|}{ Conception or pregnancy rate with housing } \\
\hline & Individually & In groups \\
\hline $\begin{array}{l}\text { Knap }(1969)^{(a)} \\
325 \text { sows }\end{array}$ & $82.6^{a}$ & $87.2^{b}$ \\
\hline $\begin{array}{l}\text { England and Spurr }(1969)^{(a)} \\
140 \text { gilts } \\
153 \text { sows }\end{array}$ & $\begin{array}{l}73.0 \\
71.0\end{array}$ & $\begin{array}{l}67.0 \\
82.0\end{array}$ \\
\hline $\begin{array}{l}\text { Jensen et al. }(1970)^{(u)} \\
\quad 240 \text { gilts }\end{array}$ & 80.0 & 82.0 \\
\hline $\begin{array}{l}\text { Schlegel and Sklenar (1972) } \\
809 \text { gilts } \\
1765 \text { sows }\end{array}$ & $\begin{array}{l}58.8 \\
69.4^{a}\end{array}$ & $\begin{array}{l}62.2 \\
73.5^{b}\end{array}$ \\
\hline $\begin{array}{l}\text { Klatt and Schlisske (1975) } \\
23 \text { sows }\end{array}$ & 90.0 & 81.9 \\
\hline $\begin{array}{l}\text { Fahmy and Dufour }(1976)^{(0)} \\
177 \text { sows }\end{array}$ & $66.5^{\circ}$ & $81.1^{b}$ \\
\hline
\end{tabular}

(a) Housing treatment imposed prior to mating and during gestation.

${ }^{a . \diamond}$ : Figures with a different superscript are significantly different $(P<0.05)$

pregnancy rate when sows are individually housed. The results of studies on the influence of the penning system during gestation on the fecundity of the gilt and sow are contradictory (England and Spurr, 1969; Jensen et al., 1970; Nygaard et al., 1970; Gustafsson, 1972; Schlegel and Sklenar, 1972; Bäckström, 1973; Klatt and Schlisske, 1975). Thus, further research is required to study the influence of the penning system prior to and after mating on the fertility and fecundity of the gilt and sow and it is essential that this research considers the role of variables such as space allowance, group size, pen design, tethering and loose housing and feeding system. For instance, Yakimchuk (1980) reported a reduction in fertility and fecundity of sows and gilts housed in groups of 20,40 and 50 compared with those housed in groups of 10 animals.

The mechanism by which individual housing may influence reproduction is not clear, but two recent studies have investigated the influence of the penning system on the physiology and behaviour of the sow. Barnett, Cronin and Winfield (1981) concluded that individually-housed sows were exhibiting a chronic stress response as evidenced by changes in adrenal function. Due to increased behavioural disturbances, Sambraus, Sommer and Kräusslich (1978) concluded that the 'well-being' of sows is adversely affected by individual housing. These two studies provide support for the view that one or more of the physiological mechanisms involved in reproduction of the female pig may be disrupted or inhibited by individual housing.

Thus, there is considerable evidence suggesting that the social environment of the sow may have a marked influence on her reproduction. Beneficial aspects of the social environment appear to be the presence of mature boars prior to mating and group housing prior to and after mating. However, further research is urgently required to define the manner in which these social factors positively influence reproduction of the sow. 


\section{Conclusions}

A review of the literature on the role of the social environment on reproduction of the pig clearly shows that the social environment is a major determinant of the sexual behaviour. Physical contact during rearing, achieved either within a group or through a wire-mesh wall, is required for the development of high levels of sexual behaviour of the boar. As far as the prepubertal gilt is concerned, contact with, and especially introduction to, mature boars during rearing positively influences oestrus expression and sexual receptivity, which in turn improves mating rate.

After puberty social environment has a further influence on the stimulation and maintenance of sexual behaviour and reproduction of the pig. Mature boars require stimulation from the presence of female pigs to maintain their potential level of sexual behaviour, while oestrus in the weaned sow appears to be stimulated by introduction to mature boars. Thus, when the two sexual partners are in proximity there appears to be coordination of sexual responsiveness, ensuring efficient reproduction. At present research has not identified the stimuli from the partners responsible for these effects and, obviously, this is the next main objective of research in this area.

In addition, penning system appears to influence reproduction of the female pig. There is evidence to indicate that individual housing at various stages of the reproductive cycle will adversely affect reproduction of the gilt and sow. Research is required to identify the factor(s) responsible and so define the penning system in terms of space allowance, group size, amount and type of contact with pigs available, etc. to facilitate efficient reproduction of the female.

Therefore, it is obvious that the social environment exerts a major influence on reproduction of the boar, gilt and sow. Many of the reproductive disorders encountered in modern pig production may be a result of a suboptimum social environment and thus marked improvements in reproductive efficiency are likely to occur by using and improving our knowledge of the role of the social environment on reproduction of the pig.

\section{Acknowledgements}

The research reported in this chapter was supported by the Australian Pig Industry Research Committee. The assistance of Mr C.G. Winfield in the preparation of this chapter is gratefully acknowledged.

\section{References}

BÄCKSTRÖM, L. (1973). Environment and animal health in piglet production. A field study of incidences and correlations. Acta vet. scand., Suppl. 41, 1-240

BARNETT, J.L., CRONIN, G.M. and WINFIELD, C.G. (1981). The effects of individual and group penning of pigs on total and free plasma corticosteroids and the maximum corticosteroid binding capacity. Gen. Comp. Endocr. 44, 219-225 
BOOTH, W.D. and BALDWIN, B.A. (1980). Lack of effect on sexual behaviour or the development of testicular function after removal of olfactory bulbs in prepubertal boars. J. Reprod. Fert. 58, 173-182

BROOKS, P.H. (1974). Oestrus detection and synchronisation in gilts and sows. In The Detection and Control of Breeding Activity in Farm Animals, (J.B. Owen, Ed.), pp. 73-83

BROOKS, P.H. and COLE, D.J.A. (1970). The effect of boar presence on the attainment of puberty in gilts. J. Reprod. Fert. 23, 435-440

COLE, D.J.A., BROOKS, P.H. and KAY, R.M. (1972). Lactational anoestrus in the sow. Vet. Rec. 90, 681-683

DÖCKE, V.F. and WORCH, H. (1963). Investigations into uterine motility and mating reactions of sows. Zuchthygiene 7, 169-178

$\ltimes$ ENGLAND, D.C. and SPURR, D.T. (1969). Litter size of swine confined during gestation. J. Anim. Sci. 28, 220-223

FAHMY, M.H. and DUFOUR, J.J. (1976). Effects of post-weaning stress and feeding management on return to oestrus and reproductive traits during early pregnancy in swine. J. Anim. Prod. 23, 103-110

FRASER, A.F. (1968a). Reproductive Behaviour in Ungulates. London and New York, Academic Press

FRASER, A.F. (1968b). The 'male effect' on reproductive responses in female farm animals. VIth Congr. Int. Reprod. A.I., Paris, II, 1661-1662

GUSTAFSSON, B. (1972). Environment and results in piglet production. Agricultural College of Sweden, November 13-14, 1972, pp. 6 (Abstract).

HEMSWORTH, P.H. and BEILHARZ, R.G. (1979). The influence of restricted physical contact with pigs during rearing on the sexual behaviour of the male domestic pig. Anim. Prod. 29, 311-314

HEMSWORTH, P.H. and GALLOWAY, D.B. (1979). The effect of sexual stimulation on the sperm output of the domestic boar. Anim. Reprod. Sci. 2, 387-394

HEMSWORTH, P.H., BEILHARZ, R.G. and BROWN, W.J. (1978). The importance of the courting behaviour of the boar on the success of natural and artificial matings. Appl. Anim. Ethol. 4, 341-347

HEMSWORTH, P.H., BEILHARZ, R.G. and GALLOWAY, D.B. (1977). Influence of social conditions during rearing on the sexual behaviour of the domestic boar. Anim. Prod. 24, 245-251

HEMSWORTH, P.H., CRONIN, G.M. and HANSEN, C. (1982). The influence of social restriction during rearing on the sexual behaviour of the gilt. Anim. Prod. (in press)

HEMSWORTH, P.H., FINDLAY, J.K. and BEILHARZ, R.G. (1978). The importance of physical contact with other pigs during rearing on the sexual behaviour of the male domestic pig. Anim. Prod. 27, 201-207

HEMSWORTH, P.H., SALDEN, N.T.C.J. and HOOGERBRUGGE, A. (1982). The influence of the post-weaning social environment on the weaning to mating interval of the sow. Anim. Prod. (in press)

HEMSWORTH, P.H., WINFIELD, C.G. and CHAMLEY, W.A. (1981). The influence of the presence of the female on the sexual behaviour and plasma testosterone levels of the mature male pig. Anim. Prod. 32, 61-65

HEMSWORTH, P.H., WINFIELD, C.G., BEILHARZ, R.G. and GALLOWAY, D.B. (1977). The influence of social conditions post-puberty on the sexual behaviour of the domestic male pig. Anim. Prod. 25, 305-309 
HILLYYER, G.M. (1976). An investigation using a synthetic porcine pheromone and the effect on days from weaning to conception. Vet. Rec. 98, 93-94

HUGHES, P.E. and COLE, D.J.A. (1976). Reproduction in the gilt. 2. The influence of gilt age at boar introduction on the attainment of puberty. Anim. Prod. 23, 89-94

HUGHES, P.E. and COLE, D.J.A. (1978). Reproduction in the gilt 3. The effect of exogenous oestrogen on the attainment of puberty and subsequent reproductive performance. Anim. Prod. 27, 11-20

HUGHES, P.E. and KIRKWOOD, R.N. (1980). Boar-induced precocious puberty in the gilt. 3/st Annual Meeting of EAAP, Munich, P 5/6. 39

ILLIUS, A.W., HAYNES, N.B. and LAMMING, G.E. (1976). Effects of ewe proximity on peripheral plasma testosterone levels and behaviour in the ram. J. Reprod. Fert. 48, 25-32

JENSEN, A.H., YEN, J.T., GEHRING, M.M., BAKER, D.H., BECKER, D.E. and HARMON, B.G. (1970). Effects of space restriction and management of pre- and post-pubertal response of female swine. J. Anim. Sci. 31, 745-750

KARLBERG, K. (1980). Factors affecting post-weaning oestrus in the sow. Nord. VetMed. 32, 183-193

KIRKWOOD, R.N. and HUGHES, P.E. (1979). The influence of age at first boar contact on puberty attainment in the gilt. Anim. Prod. 29, 231-238

KIRKWOOD, R.N. and HUGHES, P.E. (1980a). A note on the influence of 'boar effect' component stimuli on puberty attainment in the gilt. Anim. Prod. 31, 209-211

KIRKWOOD, R.N. and HUGHES, P.E. (1980b). A note on the efficacy of continuous versus limited boar exposure on puberty attainment in the gilt. Anim. Prod. 31, 205-207

KLATT, $G$. and SCHLISSKE, w. (1975). The effects on performance of minimal exercise of sows pregnant after an extremely short suckling period. Anim. Breed. Abstr. 43, 466-467 (Abstract)

KNAP, J. (1969). Effect of group and individual housing of sows after weaning on length of the interval to the first mating and conception rate. Anim. Breed. Abstr. 38, 641-642 (Abstract)

MACLEAN, C.W. (1969). Observations on non-infectious infertility in sows. Vet. Rec. 85, 675-682

MAVROGENIS, A.P. and ROBISON, O.W. (1976). Factors affecting puberty in swine. J. Anim. Sci. 42, 1251-1255

MELROSE, D.R., REED, H.C.B. and PATTERSON, R.L.S. (1971). Androgen steroids associated with boar odour as an aid to the detection of oestrus in pig artificial insemination. Br. vet. J. 127, 497-501

MEREDITH, M.J. (1979). The treatment of anoestrus in the pig : A review. Vet. Rec. 104, 25-27

MICHAEL, R.P. and ZUMPE, D. (1970). Sexual initiating behaviour by female rhesus monkeys (Macaca mulatta) under laboratory conditions. Behaviour 36, 168-186

MICHAEL, R.P., ZUMPE, D., KEVERNE, E.B. and BONSALL, R.W. (1972). Neuroendocrine factors in the control of primate behaviour. Recent Prog. Horm. Res. 28, 665-706

NYGAARD, A., AULSTAD, D., LYSO, A., KRAGGERUD, H. and STANDAL, N. 
(1970). Housing for pregnant sows. Anim. Breed. Abstr. 40, 744 (Abstract)

PETCHEY, A.M. and JOLLY, G.M. (1979). Sow service in lactation : An analysis of data from one herd. Anim. Prod. 29, 183-191

PETCHEY, A.M., DODSWORTH, T.L. and ENGLISH, P.R. (1978). The performance of sows and litters penned individually or grouped in late lactation. Anim. Prod. 27, 215-221

PETERS, J.B., FIRST, N.L. and CASIDA, L.E. (1969). Effects of pig removal and oxytocin injections on ovarian and pituitary changes in mammillectomized post-partum sows. J. Anim. Sci. 28, 537-541

PITKJANEN, I.G. (1964). Investigations on reproductive biology and A.I. in swine. Vth Congr. Int. Anim. Reprod. A.I., Trento, Vol. 6, pp. 25-30

ROBISON, O.W. (1974). Effects of boar presence and group size on age at puberty in gilts. J. Anim. Sci. 39, 224 (Abstract)

ROWLINSON, P. and BRYANT, M.J. (1976). The effect of lactating management on the incidence and timing of oestrus in lactating sows. Anim. Prod. 22, 139 (Abstract)

ROWLINSON, P., BOUGHTON, H.G. and BRYANT, M.J. (1975). Mating of sows during lactation: Observations from a commercial unit. Anim. Prod. 21, 233-241

SAMBRAUS, H.H., SOMMER, B. and KRÄUSSLICH, H. (1978). The behaviour of sows in different systems of husbandry. Ist World Congress on Ethology Applied to Zootechnics, Madrid, Vol. 1, Plenary session, pp. 99-102

SCHEIN, M.W. and HALE, E.B. (1965). Stimuli eliciting sexual behaviour. In Sex and Behaviour, (F.A. Beach, Ed.), pp. 440-482. New York, J. Wiley and Sons, Inc.

SCHLEGEL, $W$. and SKLENAR, $V$. (1972). The effect of different management systems on reproductive performance in sows. Anim. Breed. Abstr. 41, 551 (Abstract)

SCHINCKEL, P.G. (1954). The effect of the presence of the ram on the ovarian activity of the ewe. Aust. J. agric. Res. 5, 465-479

SIGNORET, J.P. (1970a). Swine behaviour in reproduction. In Effect of Disease and Stress on Reproductive Efficiency in Swine, pp. 28-45.

SIGNORET, J.P. (1970b). Reproductive behaviour of pigs. J. Reprod. Fert., Suppl. 11, 105-107

SIGNORET, J.P. (1970c). Sexual behaviour patterns in female domestic pigs (Sus scrofa L.) reared in isolation from males. Anim. Behav. 18, 165-168

SIGNORET, J.P. (1971). The reproductive behaviour of pigs in relation to fertility. Vet. Rec. 88, 34-38

SIGNORET, J.P. (1972). The mating behaviour of the sow. In Pig Production, (D.J.A. Cole, Ed.), pp. 295-313. London, Butterworths

SIGNORET, J.P. and MAULEON, P. (1962). The effect of surgical removal of the olfactory bulbs on the sexual cycle and the genital tract of sows. Annls Biol. anim. Biochim. Biophys. 2, 167-174

SIGNORET, J.P., DU MESNIL DU BUISSON, F. and MAULEON, P. (1972). Effect of mating on the onset and duration of ovulation in the sow. J. Reprod. Fert. 31, 327-330

SOMMER, B. (1980). Sows in individual pens and group housing - oestrous behaviour, parturition, fertility and damage to limbs. Anim. Breed. Abstr. 48, 619 (Abstract) 
THOMAS, H.R., KATTESH, H.G., KNIGHT, J.W., GWAZDAUSKAS, F.C., MEACHAM, T.N. and KORNEGAY, E.T. (1979). Effects of housing and rearing on age and puberty and libido in boars. Anim. Prod. 28, 231-234

VANDENBERGH, J.G. (1969). Endocrine coordination in monkeys : Male sexual responses to the female. Physiol. Behav. 4, 261-264

WALTON, A. (1960). Copulation and natural insemination. In Marshall's Physiology of Reproduction, 3rd Edition, (A.S. Parkes, Ed.), pp. 130-160. London, Longman, Green and Company

WATSON, R.H. and RADFORD, H.M. (1960). The influence of rams on the onset of oestrus in Merino ewes in spring. Aust. J. agric. Res. 11, 65-71

WHITTEN, W.K. (1956). Modification of the oestrus cycle of the mouse by external stimuli association with the male. J. Endocr. 13, 399-404

WHITTEN, W.K. (1959). Occurrence of anoestrus in mice caged in groups. $J$. Endocr. 18, 102-107

WRAthall, A.E. (1975). Reproductive Disorders in Pigs, Commonwealth Bureau of Animal Health, Review Series 11, Commonwealth Agricultural Bureau, Slough, England.

YAKIMCHUK, N.V. (1980). Conception rate and litter size of sows in relation to group size. Anim. Breed. Abstr. 48, 370 (Abstract)

YOUNG, W.C. (1957). Genetic and psychological determinants of sexual behaviour patterns. In Hormones, Brain Function and Behaviour, $(\mathbf{H}$. Hoaglan, Ed.), pp.75-98. New York, Academic Press

YOUNG, W.C., GOY, R.W. and PHOENIX, C.H. (1968). Hormones and sexual behaviour. Science 143, 212-218 